\title{
Pharmacokinetic/Pharmacodynamic Modeling in Inflammation
}

\author{
Hoi-Kei Lon, Dongyang Liu, and William J. Jusko \\ Department of Pharmaceutical Sciences, School of Pharmacy and Pharmaceutical Sciences, \\ University at Buffalo, Buffalo, NY 14214
}

\begin{abstract}
Inflammation is an array of immune responses to infection and injury. It results from a complex immune cascade and is the basis of many chronic diseases such as arthritis, diabetes, and cancer. Numerous mathematical models have been developed to describe the disease progression and effects of anti-inflammatory drugs. This review illustrates the state of the art in modeling the effects of diverse drugs for treating inflammation, describes relevant biomarkers amenable to modeling, and summarizes major advantages and limitations of the published pharmacokinetic/ pharmacodynamic (PK/PD) models. Simple direct inhibitory models are often used to describe in vitro effects of anti-inflammatory drugs. Indirect response models are more mechanism based and have been widely applied to the turnover of symptoms and biomarkers. These, along with targetmediated and transduction models, have been successfully applied to capture the PK/PD of many anti-inflammatory drugs and describe disease progression of inflammation. Biologics have offered opportunities to address specific mechanisms of action, and evolve small systems models to quantitatively capture the underlying physiological processes. More advanced mechanistic models should allow evaluation of the roles of some key mediators in disease progression, assess drug interactions, and better translate drug properties from in vitro and animal data to patients.
\end{abstract}

\section{Keywords}

inflammation; pharmacokinetics; pharmacodynamics; arthritis; modeling

\section{INTRODUCTION}

The classic symptoms of inflammation include rubor (redness), tumor (swelling), calor (heat), dolor (pain), and functio laesa (loss of function). ${ }^{1}$ An inflammatory response is beneficial since it plays an important physiological role in defense from invasion of pathogens and heralding wounds or other damage. When this protective mechanism becomes uncontrolled, it can lead to lethal outcomes, such as septic shock. ${ }^{2}$

Modeling and simulation are important for quantitation of experimental data and prediction and interpretation under new circumstances. Such approaches can help in evaluating the effectiveness of new therapeutic agents, understanding disease pathology, and facilitating the drug development process. Mechanism-based models allow assessing drug interventions on relevant biomarkers and the pathological network. ${ }^{3}$ In this review, we summarize the basis, rationale, and array of PK/PD models that describe the inflammation mechanism and processes, and the effects of anti-inflammatory agents.

*Address all correspondence to: William Jusko, Department of Pharmaceutical Sciences, School of Pharmacy and Pharmaceutical Sciences, University at Buffalo, Buffalo, NY 14214; Tel: 716-645-2855; Fax: 716-829-6569; wjjusko@buffalo.edu. 


\section{THE INFLAMMATORY PATHWAY}

\section{A. Acute Inflammation}

Much is understood about the invading agents and the subsequent inflammatory cascade. An acute inflammatory response follows four major processes, namely, invasion of infectious stimuli (often referred as inflammatory inducers), recognition of the agents by sensors, activation of inflammatory mediators, and modulation of target tissues by the mediators (Fig. 1). ${ }^{4}$ Inflammation is triggered by infection or tissue injury, where the inducers can be exogenous (e.g., pathogens, such as bacteria, virus, allergens, irritants, toxic compounds, or commensal bacteria), or endogenously produced by damaged or malfunctioning tissues. ${ }^{2}$ Examples of endogenous inducers include crystals of monosodium urate and calcium pyrophosphate dihydrate, and advanced glycation end products (AGEs). Inflammatory inducers are recognized by specific receptors (sensors) of the immune system, which are primarily toll-like receptors (TLRs) localized on immune cells such as mast cells and macrophages. ${ }^{4}$ There are 10 TLRs expressed in humans, and each binds to specific ligands and has different cell localization. ${ }^{1}$ Another inflammatory sensor is the nucleotide-binding oligomerization-domain protein (NOD)-like receptor (NLR). ${ }^{2}$ These sensors are responsible for signaling the production and migration of inflammatory mediators.

On detection of invading agents by the sensors, immune cells produce inflammatory mediators. Most of these are produced by specialized leukocytes, such as tissue-resident macrophages and mast cells, or cells in local tissues. ${ }^{2}$ Some preformed ones, such as histamine and serotonin, may be secreted from the granules of mast cells, basophils, or platelets, or converted from their precursors. ${ }^{2}$ Inflammatory mediators can be categorized into seven groups: vasoactive amines, vasoactive peptides, fragments of complement components, lipid mediators, cytokines, chemokines, and proteolytic enzymes. ${ }^{2}$ Although these mediators have characteristic roles in inflammation contributing to a specific response, some functions are overlapping (Table 1).

Inflammatory mediators elicit their effects in target cells and tissues. Some effects are ubiquitous [such as production of tumor necrosis factor (TNF)- $\alpha$, and interleukin (IL)-1], whereas others only affect specific tissues. ${ }^{2}$ The functional states of the target tissues are often the endpoints of interest where the severity of disease and PD effects can be measured. Therefore, they vary with the type of inflammatory condition being assessed.

\section{B. Chronic Inflammation}

Typically, the ultimate purpose of an inflammatory response is to remove the inciting stimuli, repair the affected sites, and allow return to homeostasis. If the elimination of invading inducers is not complete (as in transplantation), progression to chronic inflammation occurs, where the pathological mechanisms are more complicated and the outcomes are often more long lasting and detrimental. ${ }^{1}$ Unlike acute inflammation, it is difficult to assign a "general pathway" due to the diversity of conditions. Many diseases, such as obesity, type 2 diabetes, neurodegenerative diseases, and cancer, have underlying chronic inflammation. ${ }^{2,4,5}$

\section{ANTI-INFLAMMATORY AGENTS}

There are numerous effective therapeutic agents available for treating inflammation. There are seven pathways where drugs and biologics may intervene. ${ }^{1}$ The first is suppression of gene expression. This is the major mechanism of action of corticosteroids (CS), which are potent agents that mimic functions of cortisol and can inhibit transcription factors [for instance, nuclear factor (NF)-KB] that are inducers for many proinflammatory mediators. ${ }^{6}$ The CS such as prednisolone are frequent choices for combination therapy owing to long 
clinical experience. The second category is antiproliferative agents, such as methotrexate and leflunomide, which can hinder DNA synthesis by either blocking activity of essential enzymes or directly interrupting DNA replication. The third class of agents reduces expansion of immune cells. Cyclosporine, tacrolimus, and sirolimus inactivate the intracellular signaling of $\mathrm{T}$ cells, which, in turn, decreases production of proinflammatory mediators such as IL-2 and interferon (IFN)- $\gamma .{ }^{6}$ They are often used to treat immune issues in transplantation.

Most drugs in the next four immunosuppressive pathways are biologics such as antibodies and fusion proteins. There are more than 25 antibodies approved for therapy, 30 in phase 3 clinical trials, and more than 250 in phase 1 and 2 studies as of January 2011. ${ }^{7,8}$ Although structurally similar, different antibodies pose various mechanisms of action. Some of these are neutralization of specific cytokines (the fourth pathway), elimination of specific immune cells (the fifth), blockade of costimulation for T-cell activation (the sixth), and inhibition of cell adhesion (the seventh). ${ }^{1}$

Examples of approved anticytokine therapeutics include etanercept, infliximab, adalimumab (TNFa inhibitors), anakinra (IL-1 inhibitor), and tocilizumab (IL-6 receptor antagonist). ${ }^{8}$ They are engineered to specifically bind to their soluble targets, which are crucial mediators in immune signaling and have strong proinflammatory activity. One concern is that unpredictable adverse effects may sometimes occur due to the pleiotropic nature of cytokines. ${ }^{1}$ Other antibodies, such as rituximab and ofatumumab (anti-CD20), alemtuzumab (anti- CD52), and alefacept (anti-CD2), target reactive immune cells. They bind to the cellsurface receptors on antigen-bearing $\mathrm{T}$ or $\mathrm{B}$ cells, modulate their functions, then deplete them through antibody-dependent cellular cytotoxicity (ADCC) or complement-dependent cytotoxicity (CDC)..$^{1,8}$

One class of antibodies interrupts the costimulatory signals essential for complete T-cell activation. These include abatacept and belatacept. ${ }^{9}$ They contain a domain of cytotoxic Tlymphocyte antigen (CTLA)-4, which competitively inhibits the binding between CD28 (on T cells) and CD80 / CD86 (on antigen-presenting cells). ${ }^{10}$ These are used in transplantation and autoimmune diseases such as rheumatoid arthritis (RA). ${ }^{1}$ The last general pathway is the prevention of migration and recruitment of immune cells to the target tissues. Efalizumab and natalizumab, as examples, block the accumulation of inflammatory cells by disrupting the interactions between the cell surface integrins and cell adhesion molecules. ${ }^{1,8}$

The NSAIDs, such as aspirin and ibuprofen, are inhibitors of cyclooxygenase (COX) and are effective in blocking the effects of eicosanoids (e.g., prostaglandins and thromboxanes), which regulate vasodilation and pain. ${ }^{1}$ Although they have strong anti-inflammatory, antipyretic, and analgesic effects, their gastrointestinal or cardiovascular side effects are problematic. ${ }^{6}$ Histamine is an autocoid and is important in IgE-mediated hypersensitivity (allergic) reactions. It is a local mediator that can cause contraction of smooth muscle and epithelial cells, leading to edema and pain. Antihistamines, such as loratadine and rantidine, target different histamine receptors ( $\mathrm{H} 1$ and $\mathrm{H} 2$ ) and suppress clinical symptoms. ${ }^{1}$ Tyrosine kinases, such as Janus kinases (JAKs) and Bruton's tyrosine kinases (BTKs), are important in many proliferative diseases such as leukemia, which also involves cytokine production. ${ }^{11}$ Blockers of tyrosine kinase have anti-inflammatory effects. ${ }^{6}$ There are other antiinflammatory agents (such as protease inhibitors, statins, and inhibitors of complement activation) for which PK/PD modeling has not been performed.

\section{BIOMARKERS OF INFLAMMATION}

Biomarkers provide signals about pathology of diseases and pharmacology of drugs that can herald therapeutic or toxic effects. ${ }^{12,13}$ An ideal biomarker should have "consistent 
characteristics with an acceptable sensitivity and specificity representing a specific toxicity or therapeutic effect of the drug, a specific physiological response to a treatment, a pathological progression or a physiological factor." ${ }^{13}$ Numerous biomarkers have been utilized for quantifying anti-inflammatory drug responses at levels of cells, mediators, and target tissues.

\section{A. Quantification of Immune Cell Responses}

The activation of $\mathrm{T}$ cells serves in transmitting immune signals and generating immune mediators. Flow cytometry facilitates counting both total and selective immune cells with specific receptor expressions in blood. Immune cell responses can be assessed using mitogen-induced lymphocyte proliferation assays. Such assays are usually performed with splenocytes, isolated lymphocytes, or whole blood (WBLP), and can be conducted in vitro or ex vivo. ${ }^{14-16}$ WBLP is preferable because it requires small blood volumes, reflects the natural milieu, and is simple for studying drug-drug interactions (DDI). ${ }^{14-18} \mathrm{EX}$ vivo assays involve drug being dosed in study subjects before blood collection where one can assess the joint effects of drugs and metabolites. ${ }^{15,19}$

Methodology for direct lymphocyte counting is straightforward: after drug is given to study subjects, blood is collected at various time points, and the lymphocytes of interest (for example, those with a specific receptor expression, such as $\mathrm{CD}^{+}$) are quantified by flow cytometry. Such measurements are primarily for assessing cell-trafficking dynamics. ${ }^{15,20-23}$

\section{B. Quantification of Immune Mediators}

Choice of the mediators being measured depends on the pharmacology of the drug of interest. For example, concentrations of prostaglandin $\mathrm{E}_{2}\left(\mathrm{PGE}_{2}\right)$ and thromboxane $\mathrm{B}_{2}$ $\left(\mathrm{TXB}_{2}\right)$ are often quantified as indicators for COX-2 and COX-1 activities. ${ }^{24,25}$ Proinflammatory cytokines, such as TNFa and IL- $1 \beta$, are widely used biomarkers for many therapeutic agents. ${ }^{26-32}$ Measurement of target cytokine concentrations of anticytokine therapeutics allows direct assessment of their PK/PD. ${ }^{33}$ The immune mediators are usually measured by two methods. The first is use of immunoassays, such as enzymelinked immunosorbent assays (ELISAs) ${ }^{28-31,33-35}$ and radioimmunoassay (RIA), ${ }^{36}$ and the other is ex vivo measurement of enzyme activity. ${ }^{24,25,37}$ When measurement of protein concentrations of the mediators is not feasible (usually due to assay insensitivity), mRNA concentrations may be obtained by polymerase chain reaction (PCR) and used as a surrogate. 26,27

\section{Quantification of Immune Responses on Target Tissues}

Inflammation is systemic. The endpoints of interest depend on the inflammatory condition producing five main symptoms. Although numerous approaches have been developed solely to measure the severity of symptoms, some have diagnostic value. For many immune-related diseases, such as RA and systemic lupus erythematosus (SLE), the American College of Rheumatology (ACR) has established sets of criteria and scores. ${ }^{38}$

1. Redness-Redness (erythema) is often a result of vasodilation and can be a form of hypersensitivity reaction or reflect a chronic inflammatory skin condition such as psoriasis. ${ }^{22}$ This is also the basis of intradermal allergy testing. ${ }^{39}$ During treatment of psoriasis, the psoriasis area and severity index (PASI) score, which includes redness, is recorded to monitor disease severity. ${ }^{40}$ Malar rash (redness on cheek) is also one of the ACR criteria for SLE. ${ }^{38} \mathrm{PK} / \mathrm{PD}$ models of PASI score and area of redness (wheal) have been published. ${ }^{22,41,42}$ 
2. Swelling-Swelling (edema) is caused by hyperplasia and local infiltration of immune cells, and is one of the main features of RA. In animal models, edema is determined by paw volumes using a digital caliper or a plethysmometer. ${ }^{43}$ One classification criterion of RA is number of swollen or tender joints (joint involvement). ${ }^{44}$ Clinical improvement of RA after drug therapy is commonly reported using ACR criteria such as ACR20, which reflects a $20 \%$ reduction of RA severity compared with the predose condition. ${ }^{45}$ Edema is one of the most important disease endpoints for arthritis and inflammation and is included in PK/PD modeling reports of many anti-inflammatory agents. ${ }^{24,27,37,46-51}$ Besides direct determination of paw edema, the lameness score and/or motility of the animal legs are used to assess functional impairment due to edema. ${ }^{47,52,53}$

3. Fever and Pain-Fever and pain are two disease endpoints often assessed when investigating efficacy of NSAIDs. These are COX inhibitors that block the effects of prostaglandins in triggering an increase in body temperature via the hypothalamus. ${ }^{25}$ Body temperature is usually monitored by implanting a temperature $\operatorname{transmitter}^{25}$ or using a thermometer ${ }^{52-55}$ Prostaglandins also potentiate pain responses, ${ }^{1}$ NSAIDs are thus also effective as analgesics. Pain is often assessed by visual analogue scales (VAS) or the faces rating scale (FRS) in humans. These methods involve asking study subjects to profess how much pain they experience on a rating scale (e.g., from "no pain" to "pain as bad as it could be"). ${ }^{56}$ In animals, pain measurement approaches include a hind paw thermal escape model using an analgesia meter ${ }^{24,47,57}$ and a newer method referred to as "cat walk" analysis. ${ }^{25,58}$ Pain is subjective and thus exhibits higher interindividual variability than other endpoints. Other approaches, such as pain-induced functional impairment, provide more objective testing. ${ }^{59}$

4. Other Endpoints-Intragastric $\mathrm{pH}$ is measured to assess drug effects on reducing secretion of gastric acid. ${ }^{60-62}$ Agents such as $\mathrm{H} 2$ blockers are used for treatment of peptic ulcer, a chronic inflammation in the stomach usually caused by Helicobacter Pylori. ${ }^{1}$ Other PD endpoints include assessing bone mineral density (BMD) for RA. ${ }^{26,27}$

\section{PK/PD MODELING IN INFLAMMATION}

A general paradigm that provides a conceptual basis for simple PK/PD models in inflammation is shown in Fig. 2. The drug PK is always of importance in controlling the time course of exposure and frequently biophase distribution or target site exposure needs consideration. Provocations of inflammation, either natural or experimental, result in an increase of diverse mediators, biomarkers, or cells that lead to tissue damage. The mechanisms of action of anti-inflammatory drugs are typically either reduction of formation of the mediators or cells (most agents) or binding and accelerated removal of such entities (some biologics). An array of simple to complex indirect response, transduction, and targetbinding models allow quantitation of most anti-inflammatory drug responses. ${ }^{63}$

\section{A. Modeling Drug Effects on Immune Cell Responses}

We published a series of models to describe how CS interact with other agents or mediators using lymphocyte proliferation (WBLP) assays. The type of direct effect $(E)$ equation commonly used for quantitating drug effects in cell cultures is

$$
E=E_{0}\left(1-\frac{I_{\max } C}{I C_{50}+C}\right)
$$

where $E_{0}$ is the baseline, $I_{\max }$ is the maximum fractional effect, and $I C_{50}$ is the drug concentration (C) producing half-maximal inhibition. A power coefficient can be added. 
There are numerous examples where this simple nonlinear inhibition equation describes the reduction of lymphocyte proliferation by various $\mathrm{CS},{ }^{64,65}$ dehydroepiandrosterone, ${ }^{16}$ tacrolimus, methylprednisolone, ${ }^{66}$ recombinant IL-10, ${ }^{17}$ cyclosporine, ${ }^{34}$ sirolimus, ${ }^{14}$ calcium channel blockers, ${ }^{67}$ and aspirin. ${ }^{68}$ The model used for fitting ex vivo WBLP data is more complex, since it accounts for temporal changes of both lymphocyte proliferation and cell numbers during drug exposure. ${ }^{15,64}$ Figure 3 describes an experiment where prednisolone was dosed in normal subjects and inhibition of both lymphocyte trafficking and mitogen-stimulated WBLP were measured. The PK/PD model employed was able to capture both the in vitro and ex vivo actions of prednisolone. ${ }^{14}$

Determination of lymphocyte counts allows in vivo measurement of the time course of cells in blood. This type of "cell trafficking" data is usually characterized by indirect response models (IDRs), sometimes IDRs with a precursor compartment, or by target-mediated drug disposition (TMDD) models. The most common basic IDR model employed for antiinflammatory drug effects is

$$
\begin{gathered}
\frac{d R}{d t}=k_{\text {in }}\left(1-\frac{I_{\max } C}{I C_{50}+C}\right)-k_{\text {out }} R \\
R(0)=R_{0}
\end{gathered}
$$

where $R$ is response, $k_{\text {in }}$ is a zero-order production rate, $k_{\text {out }}$ is a first-order removal rate constant, $R_{0}$ is baseline, and $I_{\max }, \mathrm{C}$, and $I C_{50}$ have the same meanings as in Eq. (1). Chakraborty et al. used such a simple IDR to describe the time courses of monocytes, lymphocytes, and neutrophils after joint dosing of prednisolone and recombinant IL-10 in humans. ${ }^{19} \mathrm{Wu}$ et al. also applied this IDR for the reduction of CD11a receptor expression after efalizumab in man. ${ }^{69}$ Fisher et al. first applied Eq. (2) to describe movement of lymphocytes between blood and extravascular sites and effects of methylprednisolone. ${ }^{70}$ This model became the basis for assessing lymphocyte trafficking after which many more advanced models were developed such as incorporating the circadian rhythms of endogenous CS as well as the effects of various exogenous CS. ${ }^{15,20,21,23,64,65,71,72}$ Hong et al. modeled the interactions between cortisol and exogenous CS for lymphocyte trafficking. ${ }^{64}$ Antibody alterations of lymphocyte counts required a TMDD model for efalizumab and TRX1 (a nondepleting anti-CD4 antibody). ${ }^{22,73,74}$ TMDD models can simultaneously describe the time courses of drug (D), free receptors (R), and drug-receptor complexes (DR), and provide estimates of the drug-receptor binding and other PD parameters. ${ }^{75} \mathrm{Ng}$ et al. applied a TMDD model to describe the PK/PD of TRX1 and further utilized model simulations to make dosage suggestions for clinical studies. ${ }^{73}$

\section{B. Modeling Drug Effects on Immune Mediators}

For most studies where ex vivo stimulation of immune mediators was performed, Eq. (1) was applied to cell culture data. ${ }^{25,29,32,34,37}$ Either the percentage inhibition $\left(100 \cdot E / E_{\mathrm{O}}\right)$ or actual activity can be directly fitted to obtain $I_{\max }$ and $I C_{50}$. Qian et al. applied such a model for describing inhibition of TNFa production by DPC-333 in humans. ${ }^{29}$

Extended versions of IDRs with modified inputs (changes in kin) have been applied in modeling provocation time courses of immune mediators. ${ }^{19,28,30,31,35,36}$ Gozzi et al. published a PK/PD model to describe the lag time observed for increase in TNFa after LPS induction and effect of susalimod. ${ }^{30}$ This model is essentially a precursor IDR. ${ }^{76}$ It was modified by Chakraborty et al. ${ }^{28}$ and $\mathrm{Wyska}^{31}$ for fitting time courses of TNFa and other mediators after LPS induction along with drug inhibition. 
More advanced models have been developed for fitting more comprehensive immune mediator data to help resolve mechanisms of action. Vug-mesyster et al. used a TMDD model to account for the interaction between IL-13 and anti-IL-13 antibody. ${ }^{33}$ The model described the natural turnover of IL-13 and considered both single and double binding of IL-13 to the antibody. The model developed by Earp et al. for the effects of dexamethasone on RA disease progression using a collagen-induced arthritic (CIA) rat model ${ }^{27}$ employed a series of transduction compartments to capture the time courses of induction of TNFa, IL-6, and IL- $1 \beta$ mRNA (to be discussed later).

\section{Modeling Drug Effects on Immune Responses on Target Tissues}

Models in this category become complicated because the magnitude of the disease endpoints is controlled by more factors. In fact, biomarkers such as immune cells and mediators are the predecessors and contributors to the response factors in this group. Nevertheless, simple inhibitory models are still occasionally used for basic PD profiles. ${ }^{41,61,62}$ Ikawa et al. adapted Eq. (1) to compare the changes in intragastric $\mathrm{pH}$ after doses of lafutidine and famotidine, with addition of a biophase compartment to capture the short time delays in the response. ${ }^{62}$ An IDR model would have been more appropriate. The IDRs are widely used for describing turnover components of different disease endpoints. Simple IDR models have been applied to fit antipyretic effects of COX inhibitors. ${ }^{47,52,55,77}$

Figure 4 shows an excellent example of using a simple IDR for fitting antinociceptive effects of tolmetin in rats. ${ }^{59}$ The investigators gave a wide range of drug doses, and were able to capture all PK/PD profiles jointly using a population-fitting approach to generate the pharmacologic capacity $\left(I_{\max }\right)$ and sensitivity $\left(I C_{50}\right)$ parameters causing inhibition of the inflammatory process. The IDR models reflective of inhibition of kin and their extensions are most commonplace in modeling anti-inflammatory effects because of the paradigm that drugs usually inhibit the provocation mechanism (Fig. 2)

Advantages of using IDR models for modeling are that they are very flexible, allow easy modifications, and basically mimic the pathophysiology of many disease conditions. Some IDR models incorporate a placebo effect. This was done to describe the ACR score for RA and the PASI score for psoriasis. ${ }^{42,} 48,78 \mathrm{Hu}$ et al. modeled the placebo effect with an empirical exponential function that was included in the inhibition function for the drug effect. ${ }^{78}$ Lee et al. characterized etanercept effects in RA patients where the placebo effect was modeled with a polynomial function. ${ }^{46}$

Simple IDRs assume that the baseline of response is constant over time. Baseline responses often fluctuate over time due to physiology (e.g., circadian rhythms) and disease progression-related reasons. Added mathematical functions are needed to capture these changes. Some of these functions can be as simple as a linear function, as in studies where a first-order rate constant describes the natural production of gastric acid ${ }^{60}$ and natural paw growth. ${ }^{49}$ Josa et al. used a nonlinear time-dependent function $I R(t)$ in place of $k_{\text {in }}$ to describe the increased activity of mediators causing fever after LPS stimulation in rats. Naproxen was assumed to inhibit the $I R(t)$ function. ${ }^{54}$ There are similar models in the literature. ${ }^{24,53}$ Some models describe disease progression by applying an empirical function to replace $k_{\text {in }}$ or $k_{\text {out }}$. Giraudel et al. used a gamma function to replace $k_{\text {in }}$ in modeling kaolin-induced inflammation and effect of meloxicam in cats. ${ }^{47}$ Vasquez-Bahena et al. also used a gamma function for capturing effects of lumiracoxib. ${ }^{79}$ Other small modifications can be implemented to include disease progression in models. $(49,80,81)$ An interesting model by Krekels et al. used a precursor IDR to characterize the effect of naproxen on reducing fever with a "modified Bateman function" for $k_{\text {in }}$ to fit the time profiles of carrageenan-induced guarding index (a pain measurement) and yeast-induced fever in rats. ${ }^{25}$ 


\section{Modeling Clinical Symptoms}

Investigators in clinical pharmacology often encounter clinical data that are discrete measurements (scores) that are determined by physicians to indicate disease severity. Examples of this include the ACR20, ACR50, and ACR70 in RA, and PASI in psoriasis (see Section IV). Use of IDR models is common for modeling such data. Hu et al. published two articles applying Eq. (2) (with incorporation of placebo effect) to describe effects of golimumab on ACR scores in RA patients. ${ }^{48,51} \mathrm{Ng}$ et al. also used a IDR-based model to describe the temporal changes of PASI score in psoriasis patients receiving efalizumab. ${ }^{22}$ Other approaches, such as logistic regression, ${ }^{82-84}$ have also been used.

\section{E. Animal Scaling}

Allometric scaling offers interspecies calculation methods for physiological processes and PK based on body sizes using rules of comparative anatomy, physiology, biochemistry, and cellular structure. ${ }^{85-87}$ Lepist et al. digitized $\mathrm{S}(+)$-ketoprofen PK/PD data $\left(\mathrm{PGE}_{2}\right.$ indicating COX-1 activity and $\mathrm{TXB}_{2}$ indicating COX-2 activity) in sheep, horse, calf, and goat, and fitted these data with a two-compartment model for PK and IDR models for PD. ${ }^{88}$ The PK data scaled well, but the PD data were variable and generally did not follow any common rules. Mukherjee et al. examined a wide array of NSAIDs and demonstrated how the $\mathrm{ED}_{50}$ from the carrageenan rat paw model correlates well with the typical human dose of such drugs. ${ }^{89}$ Mager et al. reviewed related concepts and efforts to scale PD from animals to $\operatorname{man} .{ }^{90}$

A mix of data sources can be useful for translational purposes. Betts et al. utilized rat and monkey in vitro and in vivo data in a complex TMDD model to predict human PK/PD profiles of PF-04840082. ${ }^{91}$ This is a humanized anti-Dickkopf-1 (Dkk1) IgG antibody for the treatment of osteoporosis.

\section{MECHANISM-BASED MODELING IN INFLAMMATION}

More complex mechanism-based disease progression models can give insights into the temporal changes of important pathological mediators or factors and how drugs may affect different processes of disease progression. ${ }^{73}$

\section{A. Bone Homeostasis Models}

Joint destruction is one of the major symptoms in RA. Bone composition is balanced by osteoblasts and osteoclasts through the critical receptor activator of NF-KB (RANK)-RANK ligand (RANKL)-osteoprotegerin (OPG) pathway. ${ }^{92}$ In RA patients, inflammatory cytokines (TNFa, IL-1 $\beta$, and IL-6) are overproduced and stimulate production of RANKL to disturb the balance causing activation of osteoclasts with subsequent bone destruction. ${ }^{93}$

Lemaire et al. proposed the first small systems model incorporating RANK-RANKL-OPG pathway and its specific regulatory factors, transforming growth factor $\beta$ (TGF- $\beta$ ) and parathyroid hormone (PTH, the most important hormone regulating bone remodeling) to describe bone formation and resorption. ${ }^{94}$ Marathe et al. successfully applied a modified model to the antibody denosumab, an inhibitor of RANKL. ${ }^{95}$ They expanded the model to describe the effects of osteoclast-osteoblast interplay on BMD ${ }^{96}$ (Fig. 5). The model captured the effects of a range of doses of denosumab both on the resorption biomarker, Ntelopeptide of type I collagen (NTX), and on the ultimate endpoint, BMD. The addition of this clinical endpoint gave this model more power and clinical relevance. The Danhof group has addressed approaches to simplify the Lemaire model and yet provide sufficient model power to capture the physiological changes and drug effects under different meaningful scenarios. ${ }^{97}$ 
Other models of this kind include a physiologically based biological model proposed by Peterson and Riggs incorporating the previous cellular bone homeostasis model and calcium-phosphate concentrations to describe bone remodeling and calcium homeostasis. ${ }^{98}$ Changes of bone volume, impact of cell maturation on RANKL and OPG expression, and differentiation of TGF- $\beta$ impact on different bone cells were also considered in another extended cellular bone homeostasis model. ${ }^{99}$

\section{B. Mechanism-Based Models of Inflammation}

There are a limited number of small systems models of inflammation. Earp et al. developed a mechanism-based model of RA based on data obtained from CIA rats. ${ }^{26,27}$ Figure 6 displays the structure of the model. The scheme combines several simple model components. Part captures the PK of dexamethasone (as shown) and receptor-mediated dynamics of CS and the glucocorticoid receptor (GR). Several other elements are derivations of inhibitory IDRs with the addition of transduction compartments to mimic the long time delay of cytokine mRNA induction. The model successfully captured the time courses of inhibition of three proinflammatory cytokine mRNAs (only IL- $1 \beta$ is shown) and their joint provocation of paw edema as well as changes in paw BMD.

Liu et al. developed a simpler CIA rat PK/PD model, ${ }^{37}$ but there was no cytokine (mediator) data. The model has transduction steps for the time delays affecting the rate constant $k_{\text {out }}$, and the reduction of ankle edema was related to the decrease in BTK enzyme activity caused by the investigational drug GDC-0834. The inhibition in BTK enzyme activity was calculated with an inhibitory function using in vivo data collected in another group of animals and then applied as a forcing function in the model fitting. More recently, a mechanism-based model was published to describe the effects of methylprednisolone on inducible nitric oxide synthase (iNOS) mRNA expression as well as the disposition kinetics of NO in a rat model of lipopolysaccharide (LPS)-induced inflammation. ${ }^{100}$ This model combined the use of simple and precursor-pool IDR models for quantitating the turnover of iNOS mRNA expression in lung and production of NO in plasma. These types of mechanism-based models provide connections between different components for drug, mediators, and disease endpoints.

\section{System Biology-Based Models of Inflammation}

There are numerous mathematical models to describe inflammatory processes, pathological networks in immune diseases, and interactions between inflammatory mediators by systems modelers. ${ }^{101-109}$ Such a modeling approach is considered "bottom up," in which investigators subjectively harvest the best information from the literature in assembling the model. There is usually none or little experimental data collected for components in the complex mathematical schemes. These models are useful for simulations that address problems such as therapeutic interventions at different phases of inflammation ${ }^{104}$ and why patients may respond differently toward the same drug treatment. ${ }^{105}$ Often, these are questions that cannot be answered by experiments due to technical complexities or ethical difficulties. An interesting approach is called "agent-based modeling," which sets up a list of rules that the elements in the model must follow based on the known facts of the immune network. Dong et al. used this method to describe time profiles of different immune cells and mediators following endotoxin-induced acute inflammation. ${ }^{108}$

\section{FUTURE EFFORTS AND PERSPECTIVES}

Both the expansion of knowledge of inflammation and immune responses and the array of therapeutic agents with different mechanisms of action offer increasing opportunities for application of PK/PD/disease models. As noted by Earp et al., ${ }^{26}$ drug interventions allow 
probing of biological systems to disturb the natural or pathological homeostasis permitting new insights into determinants of complex systems. While simple direct, IDR, transduction, and TMDD models have proven useful in quantitating diverse types of biomarkers, symptoms, and anti-inflammatory effects, the same models can serve as components of more complex small systems models. The PK/PD models offer promise of better mechanistic understanding of drug interactions that may ultimately be of clinical benefit. They can serve a translational role in melding relevant information from diverse in vitro, animal, and clinical sources. Inflammation models will need coupling with other disease models where inflammation is an underlying factor such as in diabetes, cancer, and neurodegenerative disease. Finally, as with all models, PK/PD models enable a shared understanding of physiologic and pharmacologic systems among those interested in advancing their fields in both a conceptual and quantitative manner.

\section{Acknowledgments}

This work was supported by Grant No. GM 24211 from the National Institutes of Health and fellowship support from Amgen Pharmaceuticals (HKL) and Hoffman LaRoche (DL).

\section{REFERENCES}

1. Golan, DE.; Tashjian, AH., Jr; Armstrong, EJ.; Galanter, JM.; Armstrong, AW.; Arnaout, RA.; Rose, HS. Principles of pharmacology: the pathophysiologic basis of drug therapy. Philadelphia: Lippincott Williams \& Wilkins; 2004.

2. Medzhitov R. Origin and physiological roles of inflammation. Nature. 2008; 454(7203):428-435. [PubMed: 18650913]

3. Danhof M, de Lange EC, Della Pasqua OE, Ploeger BA, Voskuyl RA. Mechanism-based pharmacokinetic-pharmacodynamic (PK-PD) modeling in translational drug research. Trends Pharmacol Sci. 2008; 29(4):186-191. [PubMed: 18353445]

4. Medzhitov R. Inflammation 2010: new adventures of an old flame. Cell. 2010; 140(6):771-776. [PubMed: 20303867]

5. Cao Y, Dubois DC, Sun H, Almon RR, Jusko WJ. Modeling diabetes disease progression and salsalate intervention in Goto-Kakizaki rats. J Pharmacol Exp Ther. 2011; 339(3):896-904. [PubMed: 21903749]

6. Dinarello CA. Anti-inflammatory Agents: Present and Future. Cell. 2010; 140(6):935-950. [PubMed: 20303881]

7. Reichert JM. Antibody-based therapeutics to watch in 2011. MAbs. 2011; 3(1):76-99. [PubMed: 21051951]

8. Chan AC, Carter PJ. Therapeutic antibodies for autoimmunity and inflammation. Nat Rev Immunol. 2010; 10(5):301-316. [PubMed: 20414204]

9. FDA approves Nulojix for kidney transplant patients2011. $2011 \mathrm{Jul} 26$. Available from: http:// www.fda.gov/NewsEvents/Newsroom/PressAnnouncements/ucm259184.htm.

10. Kindt, TJ.; Osborne, BA.; Goldsby, RA. Kuby immunology. 6th ed.. New York: WH: Freeman \& Company; 2007.

11. Di Paolo JA, Huang T, Balazs M, Barbosa J, Barck KH, Bravo BJ, Carano RA, Darrow J, Davies DR, DeForge LE, Diehl L, Ferrando R, Gallion SL, Giannetti AM, Gribling P, Hurez V, Hymowitz SG, Jones R, Kropf JE, Lee WP, Maciejewski PM, Mitchell SA, Rong H, Staker BL, Whitney JA, Yeh S, Young WB, Yu C, Zhang J, Reif K, Currie KS. Specific Btk inhibition suppresses B cell- and myeloid cell-mediated arthritis. Nat Chem Biol. 2011; 7(1):41-50. [PubMed: 21113169]

12. Biasucci LM, Biasillo G, Stefanelli A. Inflammatory markers, cholesterol and statins: pathophysiological role and clinical importance. Clin Chem Lab Med. 2010; 48(12):1685-1691. [PubMed: 20868311]

13. Bai JP, Bell R, Buckman S, Burckart GJ, Eichler HG, Fang KC, Goodsaid FM, Jusko WJ, Lesko LL, Meibohm B, Patterson SD, Puig O, Smerage JB, Snider BJ, Wagner JA, Wang J, Walton MK, 
Weiner R. Translational biomarkers: from preclinical to clinical a report of 2009 AAPS/ACCP Biomarker Workshop. AAPS J. 2011; 13(2):274-283. [PubMed: 21448748]

14. Ferron GM, Jusko WJ. Species- and gender-related differences in cyclosporine/prednisolone/ sirolimus interactions in whole blood lymphocyte proliferation assays. J Pharmacol Exp Ther. 1998; 286(1):191-200. [PubMed: 9655860]

15. Magee MH, Blum RA, Lates CD, Jusko WJ. Pharmacokinetic/ pharmacodynamic model for prednisolone inhibition of whole blood lymphocyte proliferation. Br J Clin Pharmacol. 2002; 53(5):474-484. [PubMed: 11994053]

16. Meno-Tetang GM, Hon YY, Jusko WJ. Synergistic interaction between dehydroepiandrosterone and prednisolone in the inhibition of rat lymphocyte proliferation. Immunopharmacol Immunotoxicol. 1996; 18(3):443-456. [PubMed: 8872495]

17. Chakraborty A, Jusko WJ. Pharmacodynamic interaction of recombinant human interleukin-10 and prednisolone using in vitro whole blood lymphocyte proliferation. J Pharm Sci. 2002; 91(5):13341342. [PubMed: 11977109]

18. Piekoszewski W, Chow FS, Jusko WJ. Inhibition of phytohaemagglutinin-induced lymphocyte proliferation by immunosuppressive drugs: use of whole blood culture. Immunopharmacol Immunotoxicol. 1994; 16(3):389-401. [PubMed: 7798592]

19. Chakraborty A, Blum RA, Cutler DL, Jusko WJ. Pharmacoimmunodynamic interactions of interleukin-10 and prednisone in healthy volunteers. Clin Pharmacol Ther. 1999; 65(3):304-318. [PubMed: 10096263]

20. Mager DE, Lin SX, Blum RA, Lates CD, Jusko WJ. Dose equivalency evaluation of major corticosteroids: pharmacokinetics and cell trafficking and cortisol dynamics. J Clin Pharmacol. 2003; 43(11):1216-1227. [PubMed: 14551176]

21. Yao Z, DuBois DC, Almon RR, Jusko WJ. Pharmacokinetic/ pharmacodynamic modeling of corticosterone suppression and lymphocytopenia by methylprednisolone in rats. J Pharm Sci. 2008; 97(7):2820-2832. [PubMed: 17828751]

22. Ng CM, Joshi A, Dedrick RL, Garovoy MR, Bauer RJ. Pharmacokinetic-pharmacodynamicefficacy analysis of efalizumab in patients with moderate to severe psoriasis. Pharm Res. 2005; 22(7):1088-1100. [PubMed: 16028009]

23. Chow FS, Sharma A, Jusko WJ. Modeling interactions between adrenal suppression and T-helper lymphocyte trafficking during multiple dosing of methylprednisolone. J Pharmacokinet Biopharm. 1999; 27(6):559-575. [PubMed: 11153446]

24. Jeunesse EC, Bargues IA, Toutain CE, Lacroix MZ, Letellier IM, Giraudel JM, Toutain PL. Paw inflammation model in dogs for preclinical pharmacokinetic/pharmacodynamic investigations of nonsteroidal anti-inflammatory drugs. J Pharmacol Exp Ther. 2011; 338(2):548-558. [PubMed: 21525206]

25. Krekels EH, Angesjo M, Sjogren I, Moller KA, Berge OG, Visser SA. Pharmacokineticpharmacodynamic modeling of the inhibitory effects of naproxen on the time-courses of inflammatory pain, fever, and the ex vivo synthesis of TXB2 and PGE2 in rats. Pharm Res. 2011; 28(7):1561-1576. [PubMed: 21347567]

26. Earp JC, Dubois DC, Molano DS, Pyszczynski NA, Keller CE, Almon RR, Jusko WJ. Modeling corticosteroid effects in a rat model of rheumatoid arthritis I: mechanistic disease progression model for the time course of collagen-induced arthritis in Lewis rats. J Pharmacol Exp Ther. 2008; 326(2):532-545. [PubMed: 18448865]

27. Earp JC, Dubois DC, Molano DS, Pyszczynski NA, Almon RR, Jusko WJ. Modeling corticosteroid effects in a rat model of rheumatoid arthritis II: mechanistic pharmacodynamic model for dexamethasone effects in Lewis rats with collagen-induced arthritis. J Pharmacol Exp Ther. 2008; 326(2):546-554. [PubMed: 18448864]

28. Chakraborty A, Yeung S, Pyszczynski NA, Jusko WJ. Pharmacodynamic interactions between recombinant mouse interleukin-10 and prednisolone using a mouse endotoxemia model. J Pharm Sci. 2005; 94(3):590-603. [PubMed: 15666292]

29. Qian M, Bai SA, Brogdon B, Wu JT, Liu RQ, Covington MB, Vaddi K, Newton RC, Fossler MJ, Garner CE, Deng Y, Maduskuie T, Trzaskos J, Duan JJ, Decicco CP, Christ DD. Pharmacokinetics and pharmacodynamics of DPC 333 ((2R)-2-((3R)-3-amino-3 \{4-[2-methyl-4- 
quinolinyl) methoxy] phenyl\}-2-oxopyrrolidinyl)-N-hydroxy-4-methylpentanamide)), a potent and selective inhibitor of tumor necrosis factor alpha-converting enzyme in rodents, dogs, chimpanzees, and humans. Drug Metab Dispos. 2007; 35(10):1916-1925. [PubMed: 17656469]

30. Gozzi P, Pahlman I, Palmer L, Gronberg A, Persson S. Pharmacokinetic-pharmacodynamic modeling of the immunomodulating agent susalimod and experimentally induced tumor necrosis factor-alpha levels in the mouse. J Pharmacol Exp Ther. 1999; 291(1):199-203. [PubMed: 10490905]

31. Wyska E. Pharmacokinetic-pharmacodynamic modeling of methylxanthine derivatives in mice challenged with high-dose lipopolysaccharide. Pharmacology. 2010; 85(5):264-271. [PubMed: 20389149]

32. Radwanski E, Chakraborty A, Van Wart S, Huhn RD, Cutler DL, Affrime MB, Jusko WJ. Pharmacokinetics and leukocyte responses of recombinant human interleukin-10. Pharm Res. 1998; 15(12):1895-1901. [PubMed: 9892475]

33. Vugmeyster Y, Tian X, Szklut P, Kasaian M, Xu X. Pharmacokinetic and pharmacodynamic modeling of a humanized anti-IL-13 antibody in naive and Ascaris-challenged cynomolgus monkeys. Pharm Res. 2009; 26(2):306-315. [PubMed: 18975059]

34. Marshall JD, Kearns GL. Developmental pharmacodynamics of cyclosporine. Clin Pharmacol Ther. 1999; 66(1):66-75. [PubMed: 10430111]

35. Roy A, Mould DR, Wang XF, Tay L, Raymond R, Pfister M. Modeling and simulation of abatacept exposure and interleukin-6 response in support of recommended doses for rheumatoid arthritis. J Clin Pharmacol. 2007; 47(11):1408-1420. [PubMed: 17962428]

36. Pelligand L, King JN, Toutain PL, Elliott J, Lees P. Pharmacokinetic/ pharmacodynamic modelling of robenacoxib in a feline tissue cage model of inflammation. J Vet Pharmacol Ther. 2011; 35(1): 19-32. [PubMed: 21767277]

37. Liu L, Di Paolo J, Barbosa J, Rong H, Reif K, Wong H. Antiarthritis effect of a novel Bruton's tyrosine kinase (BTK) inhibitor in rat collagen-induced arthritis and mechanism-based pharmacokinetic/pharmacodynamic modeling: relationships between inhibition of BTK phosphorylation and efficacy. J Pharmacol Exp Ther. 2011; 338(1):154-163. [PubMed: 21521773]

38. Criteria for Rheumatic Diseases. American College of Rheumatology 2011. 2011 Aug 1. Available from: http://www.rheumatology.org/practice/clinical/classification/index.asp.

39. Intradermal allergy test reactions. 2010. 2011 Aug 1. Available from: http://www.nlm.nih.gov/ medlineplus/ency/imagepages/19345.htm.

40. Oakley, A. PASI score. 2011. [updated July 20, 2011, August 1, 2011]; Available from: http:// www.dermnetnz.org/scaly/pasi.html.

41. Olsen L, Ingvast-Larsson C, Larsson P, Brostrom H, Bondesson U, Sundqvist M, Tjalve H. Fexofenadine in horses: pharmacokinetics, pharmacodynamics and effect of ivermectin pretreatment. J Vet Pharmacol Ther. 2006; 29(2):129-135. [PubMed: 16515667]

42. Zhou H, Hu C, Zhu Y, Lu M, Liao S, Yeilding N, Davis HM. Population-based exposure-efficacy modeling of ustekinumab in patients with moderate to severe plaque psoriasis. J Clin Pharmacol. 2010; 50(3):257-267. [PubMed: 19934030]

43. Sharma JN, Samud AM, Asmawi MZ. Comparison between plethysmometer and micrometer methods to measure acute paw oedema for screening anti-inflammatory activity in mice. Inflammopharmacology. 2004; 12(1):89-94. [PubMed: 15035782]

44. Aletaha D, Neogi T, Silman AJ, Funovits J, Felson DT, Bingham CO 3rd, Birnbaum NS, Burmester GR, Bykerk VP, Cohen MD, Combe B, Costenbader KH, Dougados M, Emery P, Ferraccioli G, Hazes JM, Hobbs K, Huizinga TW, Kavanaugh A, Kay J, Kvien TK, Laing T, Mease P, Menard HA, Moreland LW, Naden RL, Pincus T, Smolen JS, Stanislawska-Biernat E, Symmons D, Tak PP, Upchurch KS, Vencovsky J, Wolfe F, Hawker G. 2010 Rheumatoid arthritis classification criteria: an American College of Rheumatology/European League Against Rheumatism collaborative initiative. Arthritis Rheum. 2010; 62(9):2569-2581. [PubMed: 20872595]

45. Felson DT, Anderson JJ, Boers M, Bombardier C, Furst D, Goldsmith C, Katz LM, Lightfoot R Jr, Paulus H, Strand V, Tugwell P, Weinblatt M, Williams HJ, Wolfe F, Kieszak S. American College 
of Rheumatology. Preliminary definition of improvement in rheumatoid arthritis. Arthritis Rheum. 1995; 38(6):727-735. [PubMed: 7779114]

46. Lee H, Kimko HC, Rogge M, Wang D, Nestorov I, Peck CC. Population pharmacokinetic and pharmacodynamic modeling of etanercept using logistic regression analysis. Clin Pharmacol Ther. 2003; 73(4):348-365. [PubMed: 12709725]

47. Giraudel JM, Diquelou A, Laroute V, Lees P, Toutain PL. Pharmacokinetic/pharmacodynamic modelling of NSAIDs in a model of reversible inflammation in the cat. Br J Pharmacol. 2005; 146(5):642-653. [PubMed: 16113689]

48. Hu C, Xu Z, Rahman MU, Davis HM, Zhou H. A latent variable approach for modeling categorical endpoints among patients with rheumatoid arthritis treated with golimumab plus methotrexate. Journal of pharmacokinetics and pharmacodynamics. 2010; 37(4):309-321. [PubMed: 20635122]

49. Lon HK, Liu D, Zhang Q, DuBois DC, Almon RR, Jusko WJ. Pharmacokinetic-pharmacodynamic disease progression model for effect of etanercept in Lewis rats with collagen-induced arthritis. Pharm Res. 2011; 28(7):1622-1630. [PubMed: 21360252]

50. Liu D, Lon HK, DuBois DC, Almon RR, Jusko WJ. Population pharmacokineticpharmacodynamic-disease progression model for effects of anakinra in Lewis rats with collageninduced arthritis. Journal of Pharmacokinetics and Pharmacodynamics. 2011; 38(6):769-786. [PubMed: 22002845]

51. Hu C, Xu Z, Zhang Y, Rahman MU, Davis HM, Zhou H. Population approach for exposureresponse modeling of golimumab in patients with rheumatoid arthritis. J Clin Pharmacol. 2011; 51(5):639-648. [PubMed: 20622199]

52. Toutain PL, Cester CC, Haak T, Laroute V. A pharmacokinetic/pharmacodynamic approach vs. a dose titration for the determination of a dosage regimen: the case of nimesulide, a Cox-2 selective nonsteroidal antiinflammatory drug in the dog. J Vet Pharmacol Ther. 2001; 24(1):43-55. [PubMed: 11348486]

53. Fosse TK, Toutain PL, Spadavecchia C, Haga HA, Horsberg TE, Ranheim B. Ketoprofen in piglets: enantioselective pharmacokinetics, pharmacodynamics and PK/PD modelling. J Vet Pharmacol Ther. 2010; 34(4):338-349. [PubMed: 20950352]

54. Josa M, Urizar JP, Rapado J, Dios-Vieitez C, Castaneda-Hernandez G, Flores-Murrieta F, Renedo MJ, Troconiz IF. Pharmacokinetic/pharmacodynamic modeling of antipyretic and antiinflammatory effects of naproxen in the rat. J Pharmacol Exp Ther. 2001; 297(1):198-205. [PubMed: 11259545]

55. Troconiz IF, Armenteros S, Planelles MV, Benitez J, Calvo R, Dominguez R. Pharmacokineticpharmacodynamic modelling of the antipyretic effect of two oral formulations of ibuprofen. Clin Pharmacokinet. 2000; 38(6):505-518. [PubMed: 10885587]

56. Freeman K, Smyth C, Dallam L, Jackson B. Pain measurement scales: a comparison of the visual analogue and faces rating scales in measuring pressure ulcer pain. J Wound Ostomy Continence Nurs. 2001; 28(6):290-296. [PubMed: 11707761]

57. Hargreaves K, Dubner R, Brown F, Flores C, Joris J. A new and sensitive method for measuring thermal nociception in cutaneous hyperalgesia. Pain. 1988; 32(1):77-88. [PubMed: 3340425]

58. Vrinten DH, Hamers FF. 'CatWalk' automated quantitative gait analysis as a novel method to assess mechanical allodynia in the rat; a comparison with von Frey testing. Pain. 2003; 102(1-2): 203-209. [PubMed: 12620612]

59. Flores-Murrieta FJ, Ko HC, Flores-Acevedo DM, Lopez-Munoz FJ, Jusko WJ, Sale ME, Castaneda-Hernandez G. Pharmacokinetic-pharmacodynamic modeling of tolmetin antinociceptive effect in the rat using an indirect response model: a population approach. $\mathrm{J}$ Pharmacokinet Biopharm. 1998; 26(5):547-557. [PubMed: 10205770]

60. Mathot RA, Geus WP. Pharmacodynamic modeling of the acid inhibitory effect of ranitidine in patients in an intensive care unit during prolonged dosing: characterization of tolerance. Clin Pharmacol Ther. 1999; 66(2):140-151. [PubMed: 10460068]

61. James LP, Marshall JD, Heulitt MJ, Wells TG, Letzig L, Kearns GL. Pharmacokinetics and pharmacodynamics of famotidine in children. J Clin Pharmacol. 1996; 36(1):48-54. [PubMed: 8932543] 
62. Ikawa K, Shimatani T, Hayato S, Morikawa N, Tazuma S. Pharmacokinetic and pharmacodynamic properties of lafutidine after postprandial oral administration in healthy subjects: comparison with famotidine. Biol Pharm Bull. 2007; 30(5):1003-1006. [PubMed: 17473452]

63. Mager DE, Wyska E, Jusko WJ. Diversity of mechanismbased pharmacodynamic models. Drug Metab Dispos. 2003; 31(5):510-518. [PubMed: 12695336]

64. Hong Y, Mager DE, Blum RA, Jusko WJ. Population pharmacokinetic/pharmacodynamic modeling of systemic corticosteroid inhibition of whole blood lymphocytes: modeling interoccasion pharmacodynamic variability. Pharm Res. 2007; 24(6):1088-1097. [PubMed: 17385022]

65. Meno-Tetang GM, Gobburu JV, Jusko WJ. Influence of gender on prednisolone effects on whole blood Tcell deactivation and trafficking in rats. J Pharm Sci. 1999; 88(1):46-51. [PubMed: 9874701]

66. Lee MJ, Pyszczynski N, Jusko WJ. Combined inhibition effects of tacrolimus and methylprednisolone on in vitro human lymphocyte proliferation. Immunopharmacol Immunotoxicol. 1995; 17(2):335-345. [PubMed: 7544367]

67. Chow FS, Jusko WJ. Immunosuppressive interactions among calcium channel antagonists and selected corticosteroids and macrolides using human whole blood lymphocytes. Drug Metab Pharmacokinet. 2004; 19(6):413-421. [PubMed: 15681895]

68. Ramakrishnan R, Jusko WJ. Interactions of aspirin and salicylic acid with prednisolone for inhibition of lymphocyte proliferation. Int Immunopharmacol. 2001; 1(11):2035-2042. [PubMed: 11606034]

69. Wu B, Joshi A, Ren S, Ng C. The application of mechanism-based PK/PD modeling in pharmacodynamic-based dose selection of muM17, a surrogate monoclonal antibody for efalizumab. J Pharm Sci. 2006; 95(6):1258-1268. [PubMed: 16637054]

70. Fisher LE, Ludwig EA, Jusko WJ. Pharmacoimmunodynamics of methylprednisolone: trafficking of helper T lymphocytes. J Pharmacokinet Biopharm. 1992; 20(4):319-331. [PubMed: 1479558]

71. Milad MA, Ludwig EA, Anne S, Middleton E Jr, Jusko WJ. Pharmacodynamic model for joint exogenous and endogenous corticosteroid suppression of lymphocyte trafficking. J Pharmacokinet Biopharm. 1994; 22(6):469-480. [PubMed: 7473077]

72. Wiczling P, Rosenzweig M, Vaickus L, Jusko WJ. Pharmacokinetics and pharmacodynamics of a chimeric/humanized anti-CD3 monoclonal antibody, otelixizumab (TRX4), in subjects with psoriasis and with type 1 diabetes mellitus. J Clin Pharmacol. 2010; 50(5):494-506. [PubMed: 19934031]

73. Ng CM, Stefanich E, Anand BS, Fielder PJ, Vaickus L. Pharmacokinetics/pharmacodynamics of nondepleting anti-CD4 monoclonal antibody (TRX1) in healthy human volunteers. Pharm Res. 2006; 23(1):95-103. [PubMed: 16308668]

74. Bauer RJ, Dedrick RL, White ML, Murray MJ, Garovoy MR. Population pharmacokinetics and pharmacodynamics of the anti-CD11a antibody hu1124 in human subjects with psoriasis. $\mathrm{J}$ Pharmacokinet Biopharm. 1999; 27(4):397-420. [PubMed: 10826130]

75. Mager DE, Jusko WJ. General pharmacokinetic model for drugs exhibiting target-mediated drug disposition. Journal of Pharmacokinetics and Pharmacodynamics. 2001; 28(6):507-532. [PubMed: 11999290]

76. Hazra A, Krzyzanski W, Jusko WJ. Mathematical assessment of properties of precursor-dependent indirect pharmacodynamic response models. Journal of Pharmacokinetics and Pharmacodynamics. 2006; 33(6):683-717. [PubMed: 17053985]

77. Garg V, Jusko WJ. Pharmacodynamic modeling of nonsteroidal anti-inflammatory drugs: antipyretic effect of ibuprofen. Clin Pharmacol Ther. 1994; 55(1):87-88. [PubMed: 8299322]

78. Hu C, Xu Z, Zhang Y, Rahman MU, Davis HM, Zhou H. Population approach for exposureresponse modeling of golimumab in patients with rheumatoid arthritis. J Clin Pharmacol. 2011; 51(5):639-648. [PubMed: 20622199]

79. Vasquez-Bahena DA, Salazar-Morales UE, Ortiz MI, Castaneda-Hernandez G, Troconiz IF. Pharmacokineticpharmacodynamic modelling of the analgesic effects of lumiracoxib, a selective inhibitor of cyclooxygenase-2, in rats. Br J Pharmacol. 2010; 159(1):176-187. [PubMed: 19958362] 
80. Earp JC, Dubois DC, Almon RR, Jusko WJ. Quantitative dynamic models of arthritis progression in the rat. Pharm Res. 2009; 26(1):196-203. [PubMed: 18758921]

81. Post TM, Freijer JI, DeJongh J, Danhof M. Disease system analysis: basic disease progression models in degenerative disease. Pharm Res. 2005; 22(7):1038-1049. [PubMed: 16028004]

82. Hutmacher MM, Krishnaswami S, Kowalski KG. Exposure-response modeling using latent variables for the efficacy of a JAK3 inhibitor administered to rheumatoid arthritis patients. Journal of Pharmacokinetics and Pharmacodynamics. 2008; 35(2):139-157. [PubMed: 18058203]

83. Hasegawa M, Imai Y, Hiraoka M, Ito K, Roy A. Modelbased determination of abatacept exposure in support of the recommended dose for Japanese rheumatoid arthritis patients. Journal of Pharmacokinetics and Pharmacodynamics. 2011; 38(6):803-832. [PubMed: 22002809]

84. Lacroix BD, Lovern MR, Stockis A, Sargentini-Maier ML, Karlsson MO, Friberg LE. A pharmacodynamic Markov mixed-effects model for determining the effect of exposure to certolizumab pegol on the ACR20 score in patients with rheumatoid arthritis. Clin Pharmacol Ther. 2009; 86(4):387-395. [PubMed: 19626001]

85. Adolph EF. Quantitative relations in the physiological constitutions of mammals. Science. 1949; 109(2841):579-585. [PubMed: 17835379]

86. Dedrick RL. Animal scale-up. J Pharmacokinet Biopharm. 1973; 1(5):435-461. [PubMed: 4787619]

87. Gillooly JF, Brown JH, West GB, Savage VM, Charnov EL. Effects of size and temperature on metabolic rate. Science. 2001; 293(5538):2248-2251. [PubMed: 11567137]

88. Lepist EI, Jusko WJ. Modeling and allometric scaling of s(+)-ketoprofen pharmacokinetics and pharmacodynamics: a retrospective analysis. J Vet Pharmacol Ther. 2004; 27(4):211-218. [PubMed: 15305849]

89. Mukherjee A, Hale VG, Borga O, Stein R. Predictability of the clinical potency of NSAIDs from the preclinical pharmacodynamics in rats. Inflamm Res. 1996; 45(11):531-540. [PubMed: 8951503]

90. Mager DE, Woo S, Jusko WJ. Scaling pharmacodynamics from in vitro and preclinical animal studies to humans. Drug Metab Pharmacokinet. 2009; 24(1):16-24. [PubMed: 19252333]

91. Betts AM, Clark TH, Yang J, Treadway JL, Li M, Giovanelli MA, Abdiche Y, Stone DM, Paralkar VM. The application of target information and preclinical pharmacokinetic/pharmacodynamic modeling in predicting clinical doses of a Dickkopf-1 antibody for osteoporosis. J Pharmacol Exp Ther. 2010; 333(1):2-13. [PubMed: 20089807]

92. Takayanagi H, Ogasawara K, Hida S, Chiba T, Murata S, Sato K, Takaoka A, Yokochi T, Oda H, Tanaka K, Nakamura K, Taniguchi T. T-cell-mediated regulation of osteoclastogenesis by signalling cross-talk between RANKL and IFN-gamma. Nature. 2000; 408(6812):600-605. [PubMed: 11117749]

93. Kearns AE, Khosla S, Kostenuik PJ. Receptor activator of nuclear factor kappaB ligand and osteoprotegerin regulation of bone remodeling in health and disease. Endocr Rev. 2008; 29(2): 155-192. [PubMed: 18057140]

94. Lemaire V, Tobin FL, Greller LD, Cho CR, Suva LJ. Modeling the interactions between osteoblast and osteoclast activities in bone remodeling. J Theor Biol. 2004; 229(3):293-309. [PubMed: 15234198]

95. Marathe A, Peterson MC, Mager DE. Integrated cellular bone homeostasis model for denosumab pharmacodynamics in multiple myeloma patients. J Pharmacol Exp Ther. 2008; 326(2):555-562. [PubMed: 18460643]

96. Marathe DD, Marathe A, Mager DE. Integrated model for denosumab and ibandronate pharmacodynamics in postmenopausal women. Biopharm Drug Dispos. 2011; 32(8):471-481. [PubMed: 21953540]

97. Schmidt S, Post TM, Peletier LA, Boroujerdi MA, Danhof M. Coping with time scales in disease systems analysis: application to bone remodeling. Journal of Pharmacokinetics and Pharmacodynamics. 2011; 38(6):873-900. [PubMed: 22028207]

98. Peterson MC, Riggs MM. A physiologically based mathematical model of integrated calcium homeostasis and bone remodeling. Bone. 2010; 46(1):49-63. [PubMed: 19732857] 
99. Pivonka P, Zimak J, Smith DW, Gardiner BS, Dunstan CR, Sims NA, Martin TJ, Mundy GR. Model structure and control of bone remodeling: a theoretical study. Bone. 2008; 43(2):249-263. [PubMed: 18514606]

100. Sukumaran S, Lepist EI, DuBois DC, Almon RR, Jusko WJ. Pharmacokinetic/pharmacodynamic modeling of methylprednisolone effects on iNOS mRNA expression and nitric oxide during LPSinduced inflammation in rats. Pharm Res. 2012; 29(8):2060-2069. [PubMed: 22422321]

101. Prince JM, Levy RM, Bartels J, Baratt A, Kane JM 3rd, Lagoa C, Rubin J, Day J, Wei J, Fink MP, Goyert SM, Clermont G, Billiar TR, Vodovotz Y. In silico and in vivo approach to elucidate the inflammatory complexity of CD14-deficient mice. Mol Med. 2006; 12(4-6):88-96. [PubMed: 16953560]

102. Pearce JA. Models for thermal damage in tissues: processes and applications. Crit Rev Biomed Eng. 2010; 38(1):1-20. [PubMed: 21175400]

103. Vodovotz Y, Clermont G, Chow C, An G. Mathematical models of the acute inflammatory response. Curr Opin Crit Care. 2004; 10(5):383-390. [PubMed: 15385756]

104. Gross F, Metzner G, Behn U. Mathematical modeling of allergy and specific immunotherapy: Th1-Th2-Treg interactions. J Theor Biol. 2011; 269(1):70-78. [PubMed: 20951144]

105. Jit M, Henderson B, Stevens M, Seymour RM. TNF-alpha neutralization in cytokine-driven diseases: a mathematical model to account for therapeutic success in rheumatoid arthritis but therapeutic failure in systemic inflammatory response syndrome. Rheumatology (Oxford). 2005; 44(3):323-331. [PubMed: 15585509]

106. Alt W, Lauffenburger DA. Transient behavior of a chemotaxis system modelling certain types of tissue inflammation. J Math Biol. 1987; 24(6):691-722. [PubMed: 3572263]

107. Thomas-Vaslin V, Altes HK, de Boer RJ, Klatzmann D. Comprehensive assessment and mathematical modeling of T cell population dynamics and homeostasis. J Immunol. 2008; 180(4):2240-2250. [PubMed: 18250431]

108. Dong X, Foteinou PT, Calvano SE, Lowry SF, Androulakis IP. Agent-based modeling of endotoxin-induced acute inflammatory response in human blood leukocytes. PLoS One. 2010; 5(2):e9249. [PubMed: 20174629]

109. Foteinou PT, Calvano SE, Lowry SF, Androulakis IP. In silico simulation of corticosteroids effect on an NFkBdependent physicochemical model of systemic inflammation. PLoS One. 2009; 4(3):e4706. [PubMed: 19274080] 


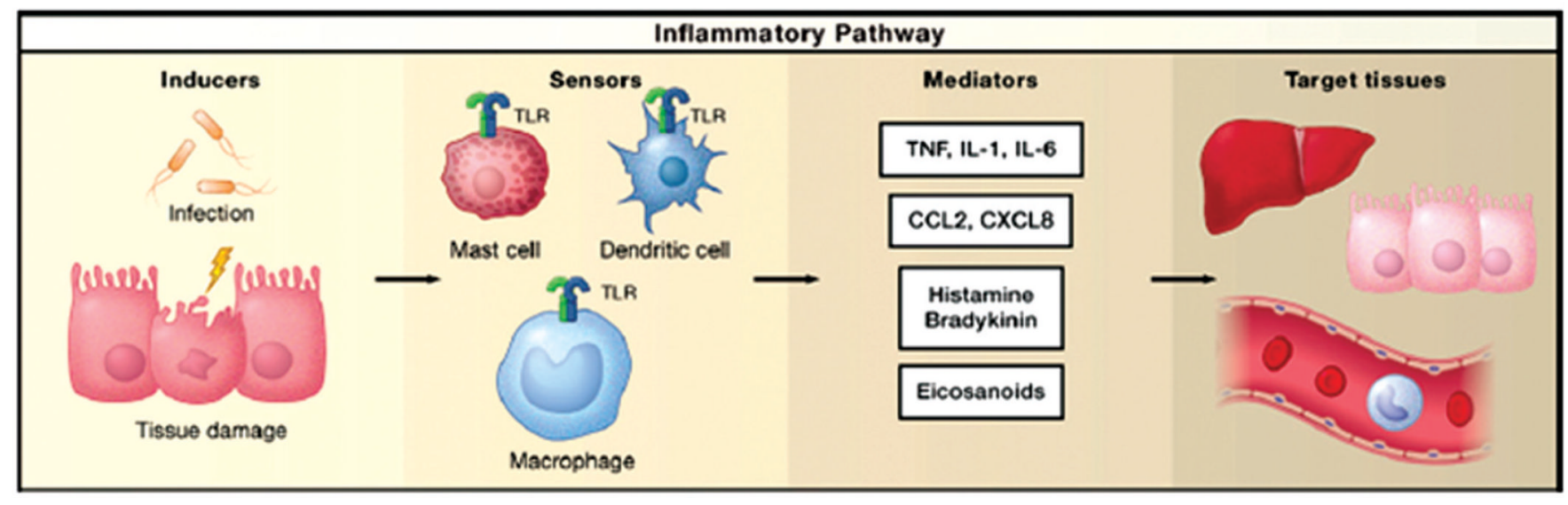

FIGURE 1.

The four main components in inflammatory pathway, adapted from Ref. 4. Inflammation is initiated by immune inducers, which are recognized by sensors (e.g., toll-like receptors) on immune cells, followed by the secretion of immune mediators (e.g., TNFa, IL-1 $\beta$, and IL-6), and finally these mediators elicit their effects on target tissues. 


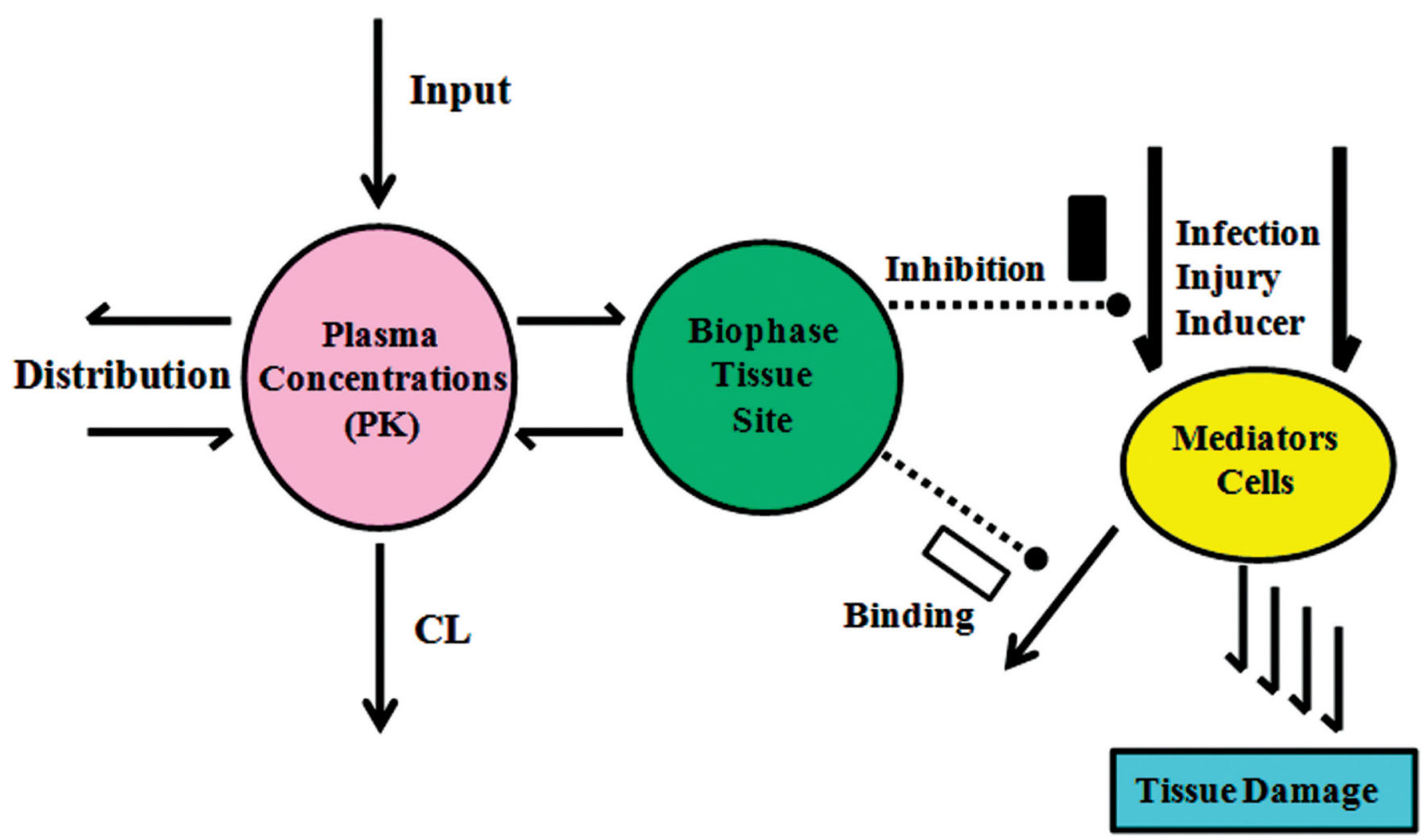

FIGURE 2.

General PK/PD paradigm that accounts for the primary factors governing the effects of most anti-inflammatory agents. The pharmacokinetics, target site drug distribution, mechanisms of drug action, inflammatory provocation processes, resultant mediators or biomarkers, and target tissues are primary components needing recognition in most models. 

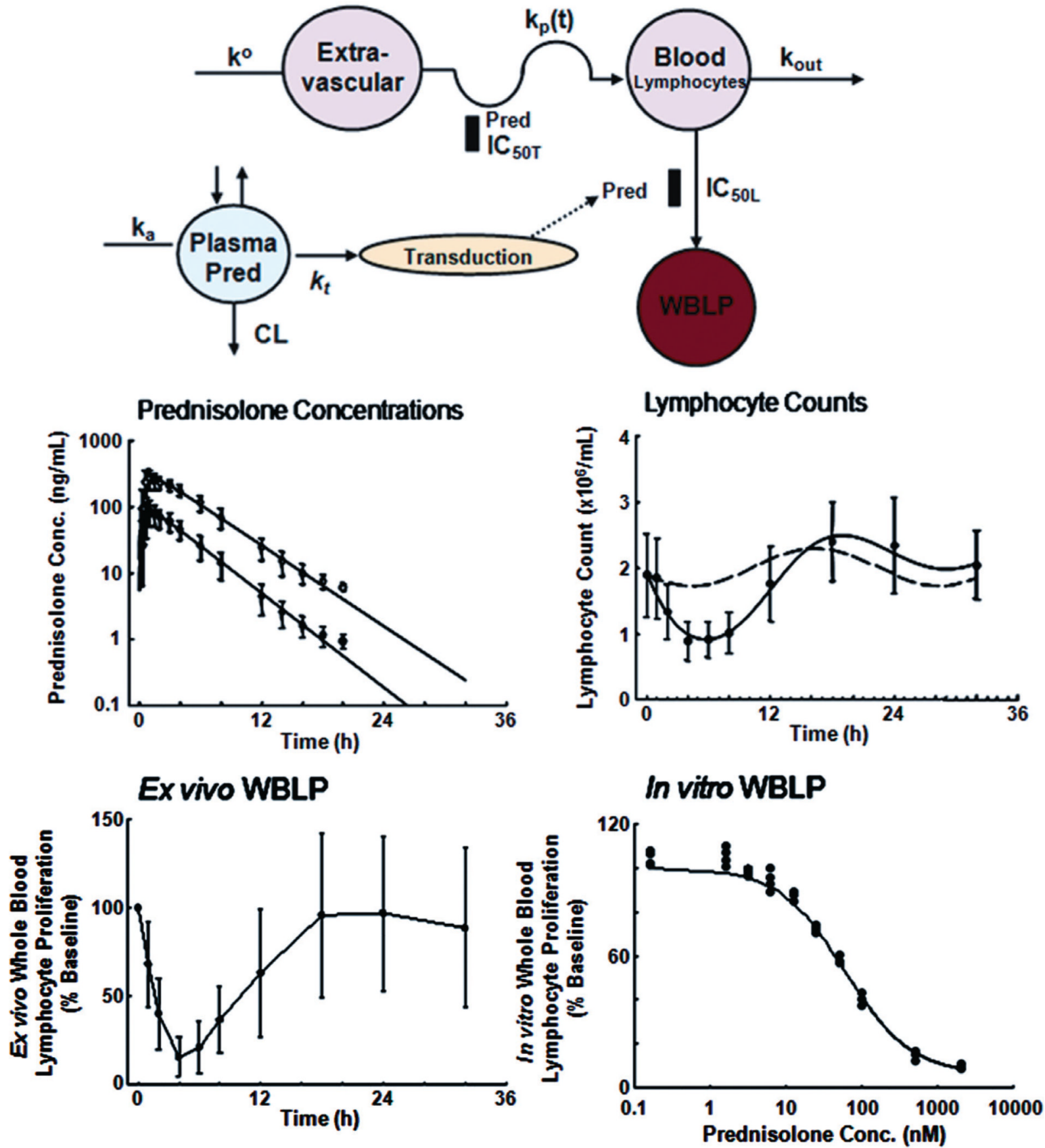

FIGURE 3 .

PK/PD modeling of the effects of prednisolone on human lymphocytes, adapted from Ref. 15. Top panel shows the model schematic used for all data fitting. Middle panels are concentration-time profiles of total (open circles) and unbound (closed circles) prednisolone (mean \pm SD), and time course of T-lymphocyte cell counts with circadian baseline (broken line) and after prednisolone (closed circles and solid line). Bottom panels depict time course of ex vivo WBLP expressed as percent of baseline (mean $\pm \mathrm{SD}$ ) and concentration-response curve of in vitro added prednisolone for inhibition of WBLP. Prednisolone acts on both lymphocyte trafficking and inhibition of mitogen-stimulated lymphocyte proliferation. 

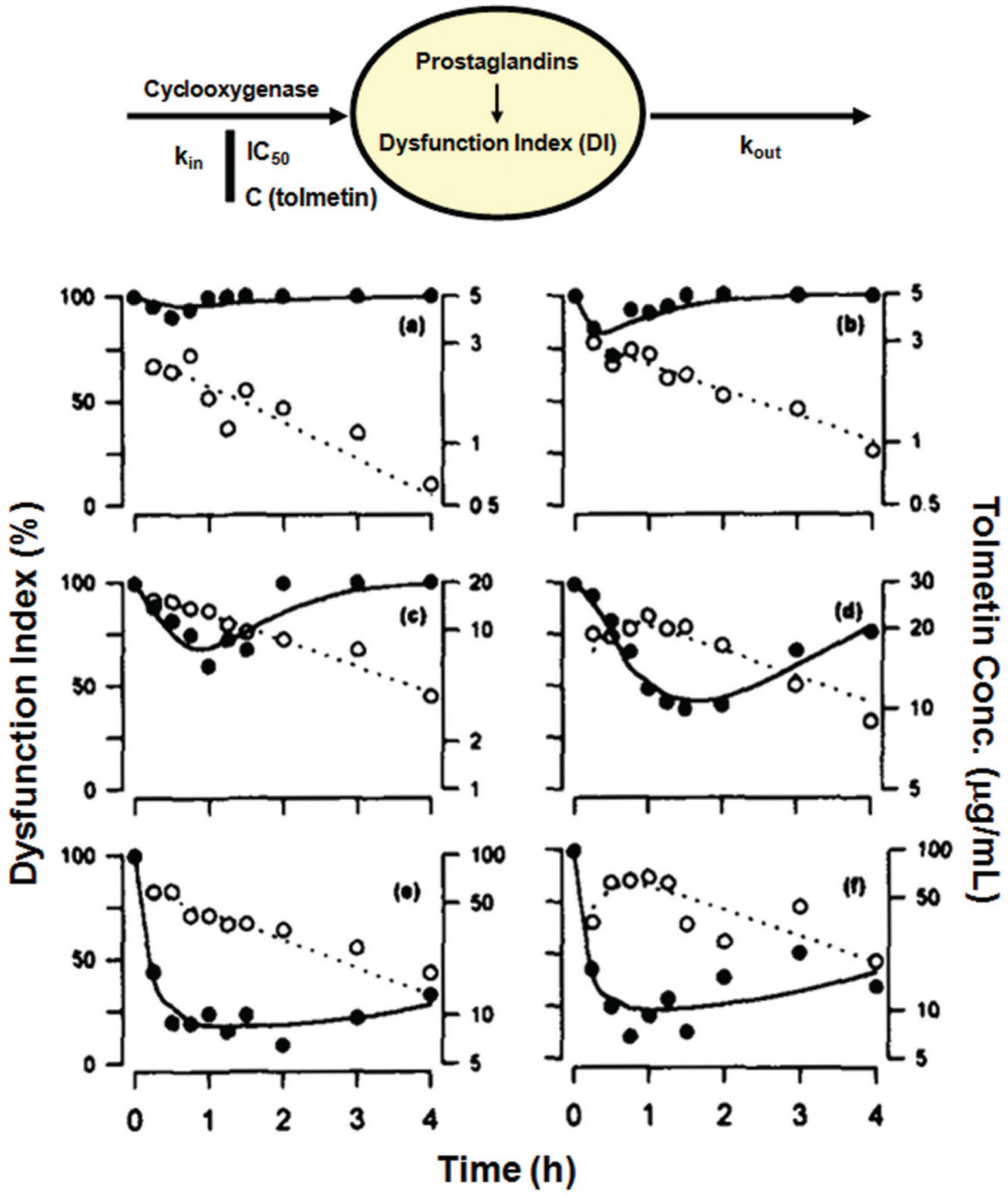

FIGURE 4.

PK/PD modeling of antinociceptive effects (dysfunction index) of tolmetin in rats, adapted from Ref. 59. Top panel shows the model schematic used for fitting of data. Lower panels show PK/PD time profiles of tolmetin in selected rats. Open circles are tolmetin blood concentrations and closed circles are dysfunction index values $(\%)$. The panels indicate doses of (a) 1 , (b) 3.2 , (c) 10 , (d) 31.6 , (e) 56.2 , and (f) $100 \mathrm{mg} / \mathrm{kg}$ tolmetin given orally to the rats. 

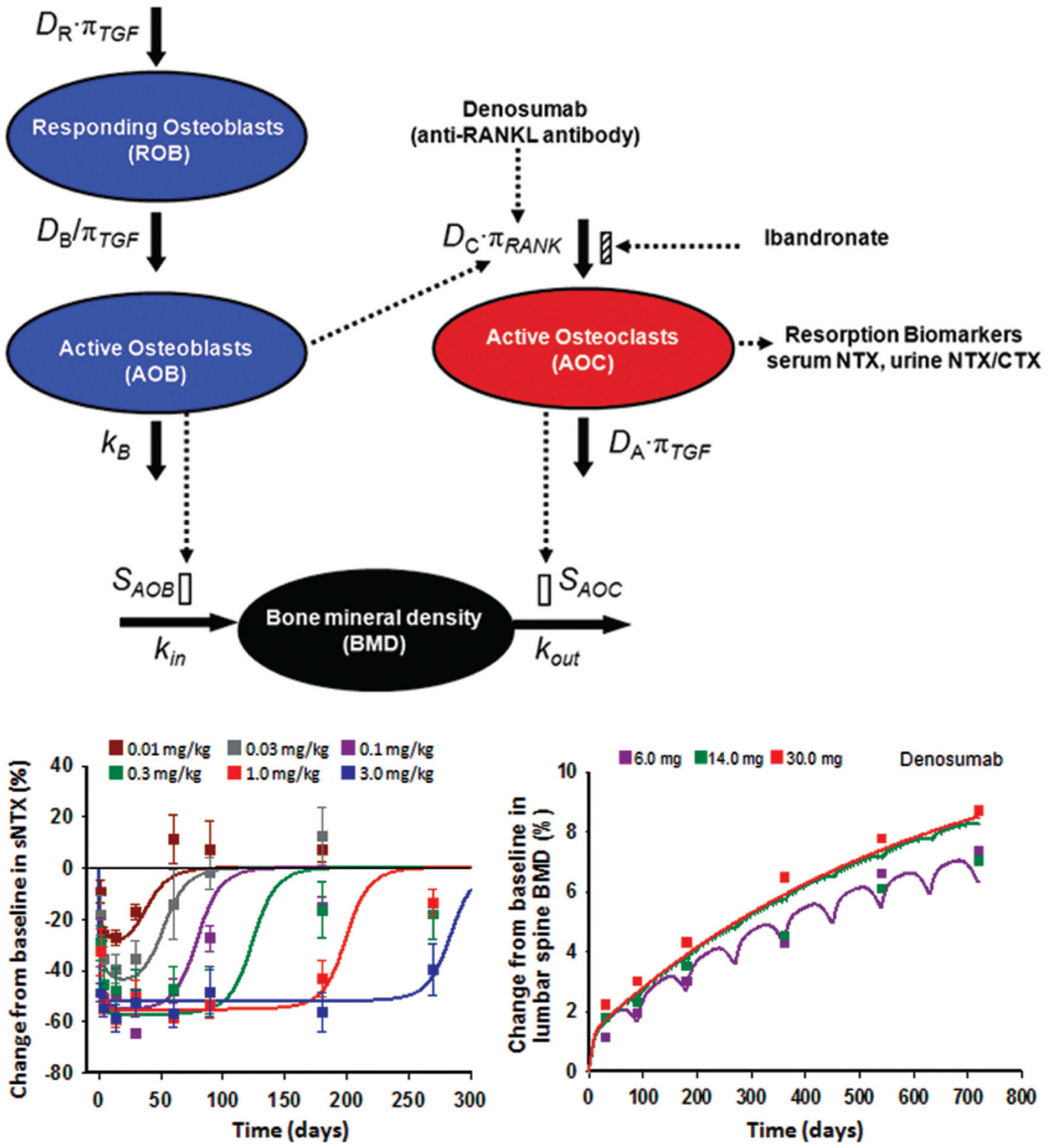

FIGURE 5.

Bone homeostasis model describing effects of denosumab and ibandronate in healthy women, adapted with permission from Ref. 96. Top panel shows model schematic used for fitting data. Left panel depicts time course of changes of serum N-telopeptide of type I collagen (NTX), a biomarker for active osteoclasts (AOC), after single subcutaneous (SC) doses of denosumab as listed. Data are mean \pm SD and normalized with baseline NTX. Right panel shows time course of lumbar spine BMD after multiple SC doses of denosumab. 

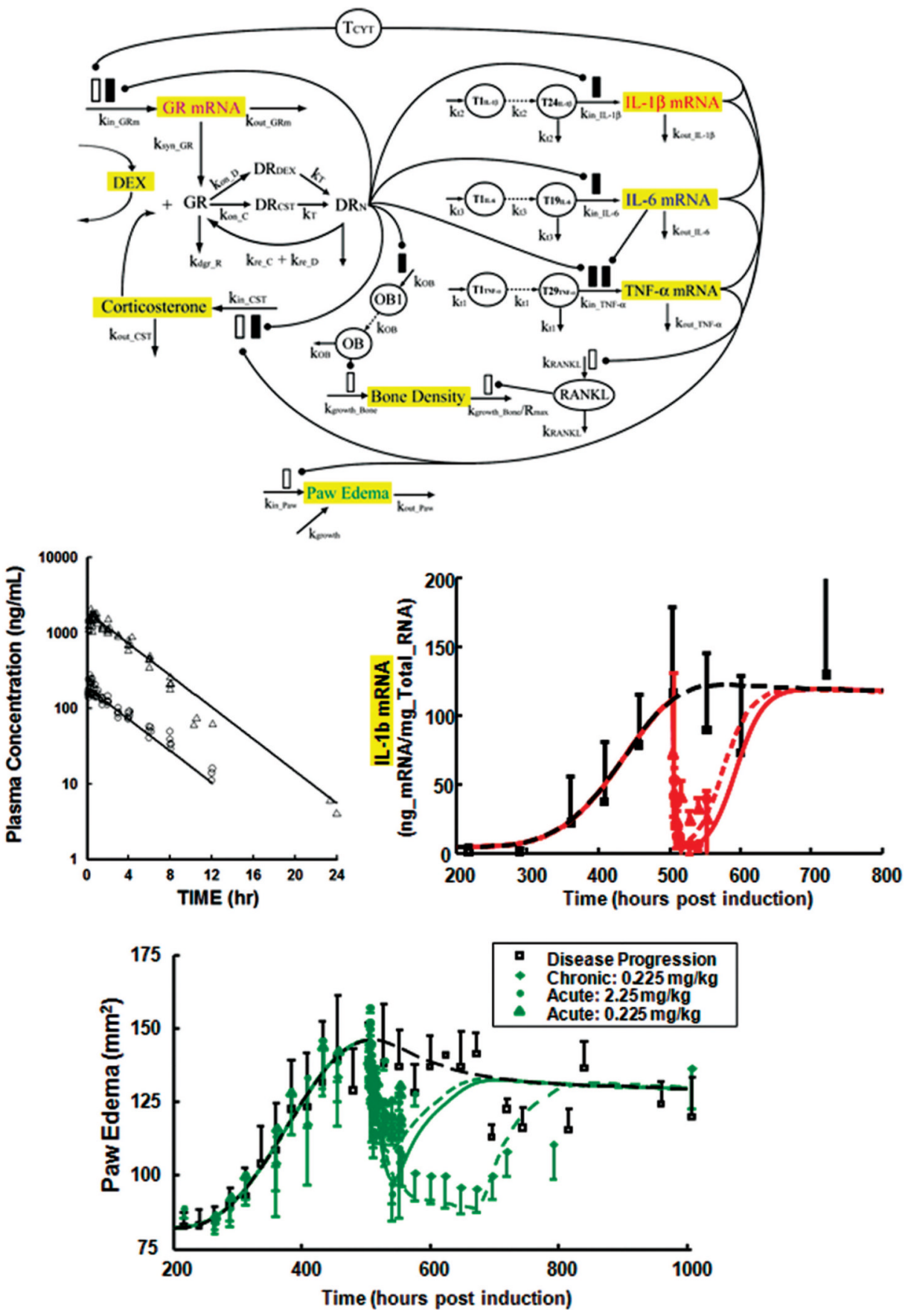

FIGURE 6.

PK/PD/disease modeling of the effects of dexamethasone in CIA rats, adapted from Ref. 27. Top panel shows model schematic used for fitting data. Center panels depict concentrationtime profiles of dexamethasone at two dose levels, i.e., $2.25 \mathrm{mg} / \mathrm{kg}$ (open triangles) and $0.225 \mathrm{mg} / \mathrm{kg}$ (circles), and time course of paw IL-1 $\beta$ mRNA concentrations (mean \pm SD) in rats after CIA induction and after single doses of dexamethasone. Bottom panel shows time course of paw edema (mean $\pm \mathrm{SD}$ ) in rats after CIA induction for untreated rats (open squares), and $2.25 \mathrm{mg} / \mathrm{kg}$ single-dose (closed circles), $0.225 \mathrm{mg} / \mathrm{kg}$ single-dose (open triangles), and $0.225 \mathrm{mg} / \mathrm{kg}$ multiple-dose (diamonds) dexamethasone groups. 
TABLE 1

Inflammatory mediators and responses, adapted from Ref. 1

\begin{tabular}{|c|c|c|}
\hline Vasodilation & Increased vascular permeability & $\begin{array}{l}\text { Chemotaxis and } \\
\text { leukocyte activation }\end{array}$ \\
\hline $\begin{array}{l}\text { Prostaglandins }\left(\mathrm{PGI}_{2} \text {, }\right. \\
\left.\mathrm{PGE}_{1}, \mathrm{PGE}_{2}, \mathrm{PGD}_{2}\right) \\
\text { Nitric oxide }(\mathrm{NO})\end{array}$ & $\begin{array}{l}\text { Histamine } \\
\text { Complement components (C3a, C5a) } \\
\text { Bradykinin } \\
\text { Leukotrienes }\left(\mathrm{LTC}_{4}, \mathrm{LTD}_{4}, \mathrm{LTE}_{4}\right) \text {, Platelet- } \\
\text { activating factor } \\
\text { Substance P } \\
\text { Calcitonin gene-related peptide (CGRP) }\end{array}$ & $\begin{array}{l}\mathrm{C}^{\mathrm{a}} \\
\mathrm{LTB}_{4} \\
\text { Lipoxins }\left(\mathrm{LXA}_{4}, \mathrm{LXB}_{4}\right) \\
\text { Bacterial products }\end{array}$ \\
\hline Tissue damage & Fever & Pain \\
\hline $\begin{array}{l}\text { Neutrophil } \\
\text { Macrophage } \\
\text { Lysosomal products } \\
\text { Oxygen radicals } \\
\text { NO }\end{array}$ & $\begin{array}{l}\text { Interleukin-1 (IL-1) } \\
\text { IL-6T } \\
\text { Tumor necrosis factor (TNF) } \\
\text { LTB }_{4} \\
\text { LXA }_{4} \text { and LXB } \\
4\end{array}$ & $\begin{array}{l}\mathrm{PGE}_{2} \text { and } \mathrm{PGI}_{2} \\
\text { Bradykinin } \\
\text { CGRP }\end{array}$ \\
\hline
\end{tabular}

